\title{
PENYUSUNAN AUDIT PROGRAM UNTUK PENGENDALIAN APLIKASI MODUL HUMAN RESOURCES PADA SISTEM TERINTEGRASI
}

\author{
Studi Kasus Pada PT. Telekomunikasi Indonesia Learning Event Area V Jawa \\ Timur \\ Bagus Satriawan Wahju Utomo ${ }^{1)}$ \\ Program Studi Sistem Informasi \\ Fakultas Sains dan Teknologi, Universitas Airlangga \\ Jl. Mulyorejo, Kampus C Unair, 60115, Surabaya \\ bagusatria-10@fst.unair.ac.id \\ Indra Kharisma Raharjana ${ }^{2}$ \\ Program Studi Sistem Informasi \\ Fakultas Sains dan Teknologi, Universitas Airlangga \\ Jl. Mulyorejo, Kampus C Unair, 60115. Surabaya \\ indra.kharisma@fst.unair.ac.id
}

\author{
Eva Hariyanti ${ }^{3)}$ \\ Program Studi Sistem Informasi \\ Fakultas Sains dan Teknologi, Universitas Airlangga \\ Jl. Mulyorejo, Kampus C Unair, 60115. Surabaya \\ eva.hariyanti@ fst.unair.ac.id
}

Diterima: 10 Maret 2015. Disetujui: 9 April 2015. Dipublikasikan: Mei 2015

\begin{abstract}
Abstrak -- Dengan mengandalkan teknologi informasi sebagai tulang punggung operasional perusahaan, aplikasi yang terlibat didalamnya harus benar-benar dapat diandalkan dan tidak terdapat kesalahan ketika digunakan. Untuk mencapai hal tersebut, perlu adanya pengendalian aplikasi. Namun, pengendalian aplikasi memerlukan pedoman agar kegiatan tersebut sesuai dengan tujuan awal sehingga aplikasi berfungsi secara efektif dan efisien. Pedoman tersebut dapat berupa audit program yang berisi prosedur untuk melakukan pengendalian yang akan dijalankan. Audit program dapat disusun menggunakan kerangka utama yang dikemukakan oleh Bellino dan Hunt. Selanjutnya, audit program disesuaikan dengan fungsional human resources (HR) sebagai studi kasus. Fungsional HR yang digunakan adalah rekrutmen dan seleksi, pelatihan dan pengembangan, kompensasi dan evaluasi kinerja. Untuk memastikan audit program dapat digunakan secara umum, dilakukan pengujian menggunakan 1 fitur pada portal internal PT.Telekomunikasi Indonesia (Telkom) sebagai studi kasus. Portal internal Telkom memiliki beberapa fitur yang digunakan untuk menjalankan operasional HR. Fitur-fitur yang ada dipilih melalui proses perhitungan nilai resiko dengan melakukan penilaian resiko. Uji coba dilakukan dengan menyesuaikan possible test yang ada pada audit program menjadi actual test.
\end{abstract}

Keywords-Audit Program, Pengendalian Aplikasi, Human Resources, Sistem Terintegrasi

\section{PENDAHULUAN}

Information Technology (IT) yang berjalan dinamis seiring perkembangan jaman membuat peran dan fungsinya semakin besar. IT tidak hanya berfungsi sebagai sarana dalam meningkatkan efektifitas dan efisiensi kerja dalam segala aspek kehidupan. Lebih dari itu, IT dewasa ini telah bertransformasi menjadi tulang punggung untuk bersaing dalam setiap aspek, mulai dari kesehatan, pendidikan, militer maupun bidang lainnya.

PT. Telekomunikasi Indonesia (Telkom) adalah salah satu Badan Usaha Milik Negara (BUMN) yang mempunyai lingkup operasional dan bisnis dibidang IT. Telkom tidak hanya sekedar menyediakan produk maupun jasa IT, lebih dari itu IT telah benar-benar menyatu dalam operasional bisnis Telkom.

Untuk menjalankan operasional bisnisnya, Telkom mengimplementasikan sebuah sistem yang saling terintegrasi antara satu area dengan area lain.

Secara historis, setiap perusahaan memiliki struktur organisasi yang memisahkan tiap area fungsional. Oleh karena itu, semakin baik sebuah perusahaan mengintegrasikan kegiatan setiap area fungsional, maka semakin sukses pula perusahaan tersebut dalam lingkungan persaingan yang sangat kompetitif seperti saat ini. Hal tersebut dikarenakan tiap area fungsional bergantung pada data dari area fungsional lainnya. Kesalahan data masukan dari satu area fungsional ke area fungsional lainnya dapat 
mengakibatkan satu kesatuan fungsional bisnis di sebuah perusahaan akan kacau.

Dengan penerapan sistem terintegrasi seperti yang dilakukan Telkom, perlu adanya pengendalian yang bertujuan untuk memastikan sistem yang digunakan tetap berjalan sesuai dengan rencana yang sudah dibuat sebelumnya. Sebuah sistem, baik kecil maupun besar memerlukan suatu pengendalian di dalamnya. Pengendalian yang dapat dilakukan pada sistem ialah dengan pengendalian aplikasi.

Pengendalian aplikasi adalah sebuah kegiatan pengontrolan yang berkaitan dengan ruang lingkup sebuah proses bisnis atau sistem aplikasi, termasuk perubahan data yang terjadi, pemisahan fungsi bisnis, penyeimbangan dari seluruh total pemrosesan, log transaksi, dan pelaporan kesalahan [1].

Sistem terintegrasi yang digunakan oleh Telkom memiliki banyak fitur yang saling berhubungan. Dengan dilakukannya pengendalian aplikasi, nantinya dapat diketahui kesesuaian antara output pada suatu fitur untuk menjadi input pada fitur lainnya. Pada penelitian ini, fokus pengendalian aplikasi hanya mencakup pengendalian masukan dan keluaran. Selain itu, pengendalian aplikasi akan melakukan cek terkait keefektifan dan keefisiesian dalam pengoperasiannya.

Kegiatan pengendalian aplikasi tidak bisa dilakukan tanpa ada pedoman. Pedoman untuk melakukan pengendalian aplikasi dapat diwüudkan dalam sebuah Audit Program. Audit Program adalah suatu dokumen yang berisikan langkah-langkah terinci untuk mengumpulkan dan menganalisa bukti-bukti temuan audit untuk mencapai tujuan dari audit 137. Audit Program bertujuan untuk memandu memastikan aplikasi yang akan digunakan nantinya benar-benar bebas dari kesalahan ketika beroperasi secara cepat, tepat dan akurat. Dewasa ini masih belum ada suatu Audit Program yang secara rinci membantu untuk melakukan kegiatan pengendalian aplikasi. Audit Program sangat diperlukan agar setiap akan melakukan kegiatan pengendalian aplikasi, ada sebuah pedoman untuk standar yang harus dilakukan dalam kegiatan pengendalian aplikasi.

Pada penelitian ini, penulis akan fokus untuk merumuskan audit program untuk melakukan pengendalian aplikasi pada modul Human Resources (HR). Untuk mernastikan audit program yang disusun dapat diimplementasikan pada kegiatan pengendalian aplikasi, audit program akan diujicoba pada salah satu fitur yang terdapat pada Portal Internal Telkom. Fitur yang digunakan sesuai dengan nilai resiko tertinggi hasil dari penilaian resiko.

\section{TinjauAn PUSTAKA}

Pengendalian aplikasi merupakan suatu prosedur yang terprogram yang didesain untuk mengatasi berbagai potensi kendala atau gangguan terhadap aplikasi-aplikasi spesifik seperti penggajian, pembelian, dan pengeluaran kas [4]. Prosedur pengendalian tersebut harus dibentuk oleh suatu entitas untuk memastikan bahwa semua dokumen sumber memiliki otorisasi, akurat, lengkap, jelas, dan masuk ke dalam sistem atau dikirim ke tujuan yang tepat dengan tepat waktu pula. Hal ini dikarenakan setiap entitas tidak ingin data-data yang menjadi sumber informasi penting dan berguna tersebut direkayasa menjadi data yang salah atau tidak valid oleh orang yang tidak memiliki wewenang [6]. Untuk mencapai hal tersebut, pengendalian aplikasi memerlukan pedoman agar kegiatan tersebut sesuai dengan tujuan awal sehingga aplikasi berfungsi secara efektif dan efisien. Pedoman tersebut dapat berupa audit program yang berisi prosedur tnituk melakukan pengendalian yang akan dijalankan.

Audit program disusun dengan teknik analisis deskriptif. Analisis deskriptif berarti bahwa data yang telah didapat akan dibandingkan dengan teori-teori yang didapat dari studi literatur serta berdasarkan penilaian resiko yang sudah diakukan terlebih dahulu [4]. Sebagai pedoman dalam penyusunan audit program mengacu pada uraian pengendalian aplikasi secara umum dan tes yang disarankan untuk setiap kontrol yang disediakan oleh grup AXA [3]. Agar audit program dapat digunakan secara umum, perlu adanya penyesuaian dengan teori-teori yang sejalan. Selanjutnya penggunaan audit program sebagai pedoman pengendalian aplikasi dapat menggunakan possible test yang ada didalamnya untuk memastikan kontrol yang ada pada tiap domain. Hanya saja dengan perbedaan latar belakang yang dimiliki oleh tiap aplikasi pada tiap perusahaan, possible test yang ada harus disesuaian menjadi actual test. Actual test perlu disesuaikan dengan possible test agar pengendalian aplikasi dapat terarah dan tetap sesuai dengan latar belakang aplikasi yang dinilai.

\section{Metode Penelitian}

\section{A. Perbandingan Fungsionalitas Human Resources (HR) Secara Umum Dengan Yang Ada Pada Telkom}

Perbandingan fungsionalitas HR secara umum dengan yang ada pada Telkom bertujuan untuk mengetahui kesamaan maupun perbedaan sebagai acuan dalam menyusun audit program. Pada tahap ini akan dibahas mengenai fungsional HR, yakni fungsi rekrutmen dan seleksi, pelatihan dan pengembangan, kompensasi dan evaluasi kinerja. Melihat dari fungsifungsi yang ada, akan dilihat pula keterlibatan TI dalam menjalankan fungsionalitas tersebut. Hal tersebut akan dilihat dari fitur apa saja yang digunakan oleh Telkom. Fungsionalitas secara umum akan diulas berdasarkan hasil studi pustaka, sedangkan fungsionalitas pada Telkom didapat dari observasi sistem dan wawancara dengan OFF 1 Learning Event Area V Jawa Timur. 


\section{B. Identifikasi dan Penilaian Resiko}

Identifikasi resiko dilakukan dengan tujuan mengetahui resiko-resiko apa saja yang mungkin timbul dari penggunaan aplikasi terhadap fungsional perusahaan secara keseluruhan. Dari identifikasi resiko yang didapat, dilakukan penilaian resiko. Penilaian resiko dilakukan dengan cara menghitung besaran nilai resiko yang mungkin muncul dalam pengoperasian sistem. Resiko dinilai dari kemungkinan timbul, dampak yang mungkin dihasilkan, serta efek pada unit bisnis lainnya. Hasil dari penilaian resiko akan digunakan sebagai dasar penyusunan audit program dengan pemilihan aplikasi yang memiliki nilai resiko terbesar.

\section{Penyusunan Audit Program}

Audit Program disusun dengan teknik analisis deksriptif. Dalam penelitian ini, analisis deskriptif dilakukan dengan membandingkan fungsional HR standar yang didapat dari studi pustaka dengan fungsional HR yang ada di PT Telkom. Proses bisnis HR yang ada pada Telkom seperti proses bisnis HR standar. Karena standar, maka akan menjadi dasar penyusunan audit program.

Audit program disusun untuk menjadi pedoman dalam melakukan pengendalian aplikasi. Audit program disusun dengan acuan uraian pengendalian aplikasi secara umum dan tes yang disarankan untuk setiap control yang disediakan oleh grup AXA

\section{Uji Coba Audit Program}

Salah satu aplikasi teknis dari pengendalian aplikasi adalah uji coba audit program. Pengendalian aplikasi dilakukan dengan mengimplementasikan possible test yang ada. Dengan latar belakang aplikasi yang berbeda pada tiap perusahaan, ada beberapa possible test yang mungkin tidak dapat diimplementasikan. Dengan demikian, perlu adanya penyesuaian terlebih dahulu pada audit program. Penyesuaian yang dapat dilakukan adalah dengan membuat actual test. Actual test disusun berdasarkan possible test yang dapat dilakukan pada sebuah aplikasi merujuk pada dinamika proses aplikasi yang menjadi obyek penelitian.

\section{TASIL DAN PEMBAHASAN}

\section{A. Perbandingan fungsionalitas Human Resources (HR) secara umum dengan yang ada pada PT. Telkom \\ 1) Pola Rekrutmen dan Seleksi}

Rekrutmen secara umum dilakukan melalui tahaptahap penentuan kebutuhan pegawai, kemudian dilanjutkan dengan seleksi awal untuk menentukan kesesuaian calon pegawai dengan kebutuhan yang tersedia. Dilanjutkan tes dan interview sebagai langkah inti untuk memastikan bahwa calon pegawai yang nantinya diterima memang sesuai dengan kriteria.

Pola yang hampir sama juga diterapkan oleh Telkom, hanya saja kebijakan rekrutmen yang ada pada Telkom ialah terpusat dan data kebutuhan pegawai telah berada pada database system. Sehingga ketika Telkom membutuhkan pegawai, system yang ada telah dengan lengkap memberi info terkait posisi apa saja yang dibutuhkan hingga kualifikasi yang dibutuhkan untuk mengisi posisi tersebut.

Telkom menggunakan fitur yang ada pada portal internal untuk menjalankan fungsional bisnis. Fiturfitur yang menjadi fungsional rekrutmen dan seleksi adalah Pensiun Dini (PenDi), e-Recruitment, Fast Track, Masa Persiapan Pensiun (MPP), Retirement. Tidak semua fitur berhubungan langsung dengan fungsionalitasnya, namun tiap fitur memiliki peranannya masing-masing untuk mengumpulkan data terkait kebutuhan pegawai dan merekomendasikan diadakannya proses rekrutmen:

\section{2) Pola Pelatihan dan Pengembangan}

Secara umum pola pelatihan yang dilakukan oleh perusahaan ialah dengan membagi menjadi 2 jenis, yaitu pelatihan awal atau biasa disebut pelatihan induksi dan juga pelatihan sebagai hasil dari evaluasi kinerja. Pelatihan induksi biasa diberikan bagi pegawai yang baru saja diterima mengisi posisi kosong pada sebuah perusahaan. Pelatihan induksi berisi tentang pengetahuan dasar mengenai job description yang nantinya harus dilakukan oleh pegawai tersebut. Berbeda dengan latihan induksi, pelatihan periodik dilakukan berdasarkan analisis evaluasi kinerja. Ketika hasil analisis memperlihatkan seorang pegawai kurang baik dalam menjalankan sebuah tugas, maka akan ada pelatihan mengenai tugas yang diselesaikan pegawai tersebut dengan kurang baik.

Pelatihan pada telkom memiliki pola yang sedikit berbeda. Selain latihan induksi, telkom memiliki pelatihan-pelatihan terstruktur yang dapat dilakukan oleh masing-masing pegawai. Namun hal tersebut dilakukan atas dasar kebutuhan untuk kenaikan pangkat atau mengisi posisi yang diinginkan oleh pegawai tersebut. Latihan-latihan tersebut dibedakan berdasarkan kebutuhan-kebutuhan kemampuan yang harus dimiliki seorang pegawai untuk mengisi posisi yang diinginkan.

Pada fungsional pelatihan dan pengembangan, Telkom juga menggunakan fitur-fitur dari portal internal. Fitur-fitur yang digunakan adalah SPPD Training, e-Learning, Distinct Job Manual (DJM), Telkom Learning Card, Collaboration Center, dan Portal Berita. Hasil pelatihan yang ada pada tiap fitur tersbut akan menjadi salah satu komponen penilaian pada fungsionalitas evaluasi kinerja.

3) Pola Kompensasi 
Kompensasi secara umum dibagi menjadi 2 jenis. Kompensasi pasti dan kompensasi berupa insentif lainnya. Pola kompensasi akan memastikan pencairan kompensasi pasti berdasarkan absensi pegawai. Selain itu untuk kompensasi lainnya mengikuti sesuai dengan peraturan perusahaan, seperti masalah bonus atau tunjangan lainnya. Sebelum menjadi kompensasi bersih, biasanya dari perusahaan akan membuat perhitungan pajak penghasilan untuk tiap pegawai. Sehingga kompensasi bersih yang diterima oleh pegawai ialah kompensasi bersih, bonus atau tunjangan serta perhitungan pemotongan pajak penghasilan.

Sama dengan yang dilakukan telkom, hanya saja bonus atau tunjangan yang diberikan tidak selalu berupa uang. Hal tersebut bisa diberikan dalam bentuk lain. Selain itu, setiap pegawai tidak selalu mendapat bonus setiap bulannya, bonus diberikan bergantung dari hasil evaluasi kinerja, ketika pegawai memiliki kinerja yang baik, maka dia akan menerima bonus.

\section{4) Pola Evaluasi Kinerja}

Evaluasi kinerja secara umum akan berpengaruh pada ranah pelatihan dan pengembangan serta kompensasi. Hal ini dikarenakan hasil dari evaluasi kinerja akan menentukan sebarapa baik/buruk kinerja pegawai pada suatu masa. Ketika hasil kerja pegawai tidak memenuhi standar dari apa yang seharusnya dihasilkan, perusahaan bisa saja menuntut pegawai untuk mengikuti pelatihan yang dibutuhkan. Selain itu ketika kinerja pegawai sedang tidak bagus, kompensasi yang didapat juga akan berkurang, jang dalam hal ini biasa berupa bonus atau tunjangan.

Di telkom, pola evaluasi kinerja tidak terlalu berpengaruh pada pola pelatihan. Namun pola evaluasi akan sangat berpengaruh pada fungsi kompensasi. Ketika hasil evaluasi kinerja pegawai mendapat nilai yang tinggi, pegawai akan mendapat kompensasi yang setimpal. Selain itu, ketika hasil evaluasi kinerja pegawai kurang memuaskan menurut pegawai, hal tersebut dapat didiskusikan kembali dengan atasan. Bukan berarti terdapat proses negosiasi, namun lebih kepada mencari penjelasan terkait nilai kinerja yang didapat pegaval

Pada fungsional evaluasi kinerja, Telkom juga mengandalkan portal internal. Fitur-fitur yang digunakan dalam mengevaluai kinerja pegawai adalah SKI/NKI, Kampiun, Competency Asessment, dan CEO Message.

\section{B. Penilaian Resiko Aplikasi PT.Telekomunikasi Indonesia, Tbk}

Dalam kegiatan penilaian resiko, dilakukan penilaian resiko dengan menggunakan kuesioner. Format kuesioner sesuai dengan 8 faktor resiko yang diuraikan oleh Christine Bellino dan Steve Hunt. Tiap faktor resiko memiliki tingkat prosentase berbedabeda. Faktor-faktor resiko yang dilibatkan dalam kuesioner penelitian ini diantaranya fakta bahwa fitur tersebut adalah fitur kunci (20\%), efektifitas desain pengendalian aplikasi $(10 \%)$, keadaan aplikasi berupa paket atau modul yang dapat dikembangkan sendiri (10\%), berhubungan dengan lebih dari 1 proses bisnis $(10 \%)$, frekuensi perubahan $(10 \%)$, kompleksitas perubahan (10\%), dampak pada bagian keuangan (15\%), dan efek dari efektifitas kontrol IT secara keseluruhan (15\%). Angka yang tertera pada tiap faktor menunjukkan prosentase untuk mengukur nilai resiko pada fitur-fitur yang ada pada portal internal Telkom. Kuesioner melibatkan 8 responden yang kesehariannya berkutat pada portal internal Telkom.

Hasil dari kuesioner mendapatkan bahwa fitur yang mendapat nilai resiko tertinggi pada tiap fungsionalitas ialah fitur SPPD Training, SKI/NKI, Cuti dan Pensiun Dini. Fitur SPPD Training mendapat nilai resiko tertinggi, yait 455,625 . Hasil penilaian resiko dapat dilihat pada tabel 1.

\section{Penyusunan Audit Program}

Penyusunan audit program disesuaikan dengan pedoman yang dibuat oleh Christine Bellino dan Steve Hunt untuk AXA [1]. Selain itu, penyusunan juga menggunakan referensi lain yakni buku dari Ron Weber dan best practices dari Chris Davis, Mike Schiller dan Kevin Wheeler [2]. Dengan menggunakan pedoman AXA sebagai landasan utama, maka domain yang ada selama sesuai dengan penjabaran fungsional HR secara umum tidak akan diubah. Perubahan dilakukan ketika ada hal yang tidak bisa diimplementasikan secara umum untuk aplikasi lain dalam modul HR. Kerangka audit program yang digunakan ialah dengan menggunakan 6 pengendalian utama yang masing-masing memiliki domain serta tes yang perlu dilakukan. Enam pengendalian utama yang digunakan ialah :

\section{1) Pengendalian akses dan masukan}

Pengendalian akses dan masukan mempunyai 4 domain [2]. namun untuk tes yang mungkin dilakukan untuk menguji tiap domain telah disesuaikan dengan mempertimbangkan hal-hal secara umum yang ada di luar AXA. Penyesuaian yang dilakukan diantaranya possible test pada domain otorisasi dan override otomatis dengan menambahkan memastikan adanya fungsi administrator sistem. Selain itu, penyesuaian juga dilakukan pada domain pemisahan tugas dan hak akses otomatis. Penyesuaian yang dilakukan meliputi control serta possible test pada domain tersebut.

\section{2) Pengendalian file dan transmisi data}

Pada pengendalian file dan transmisi data, kerangka utama yang dikemukakan Bellino dan Hunt sudah cukup untuk memenuhi kebutuhan audit program yang ditujukan untuk kegiatan pengendalian aplikasi secara umum. Hanya saja ada penambahan possible test pada domain pengendalian transmisi file dengan meminjau aktifitas melalui log aplikasi. Hal tersebut perlu dikarenakan sesuai dengan control yang diutarakan Bellino dan Hunt, disebutkan bahwa pemeriksaan 
konten termasuk didalamnya adalah tanggal, waktu, dan jumlah data dimana hal-hal tersebut dapat dilihat melalui log aplikasi.

\section{1) Pengendalian proses}

Pada pengendalian proses, terdapat domain yang dihapus. Domain tersebut adalah otomasi fungsionalitas dan masa berlaku. Domain tersebut dihapus karena melakukan kontrol terhadap aplikasi khusus yang terdapat pada grup AXA. Dengan demikian tidak dapat diterapkan secara umum. Selain itu, masalah pengendalian masa berlaku sudah terdapat pada pengendalian input dan akses pada domain penundaan item.

Penyesuaian lain yang dilakukan pada pengendalian proses terdapat pada possible test yang mengikuti domain cek duplikasi data. Penyesuaian yang dilakukan dengan menambah pengecekan terkait pemisahan data sebagai master dan backup.

\section{2) Pengendalian keluaran}

Untuk pengendalian keluaran, pada kerangka utama dari Bellino dan Hunt menyatakan hal yang terlalu teknis mengarah pada laporan buku besar yang dalam hal ini laporan finansial. Hal tersebut dikarenakan yang menjadi studi kasus dari Bellino dan Hunt adalah aplikasi grup AXA. Agar audit program nantinya dapat digunakan pada aplikasi secara umum. penyesuaian yang dilakukan adalah dengan mengganti domain menjadi pengendalian distribusi laporan.

Domain tersebut didapat dari Weber, terkait bahasan masalah pengendalian aplikasi. Untuk kontrol dan possible test yang digunakan pada domain tersebut, penyesuaian merujuk pađa Setyawan.

\section{3) Pengendalian file master dan standing data}

Penyesuaian yang dilakukan pada pengendalian file master hanya sekedar pada possible test yang perlu dilakukan pada domain pembaharuan otorisasi. Penyesuaian kembali merujuk pada best practices yang dikemukakan Davis, Schiller dan Wheeler. Possible test yang ditambahkan adalah memastikan proses deprovisioning telah dilakukan sebagaimana mestinya. Proses deprovisioning sendiri adalah proses menghapus atau menutup akun pengguna dalam layanan ketika pengguna ketika otorisasinya untuk menggunakan layanan berhenti [5]

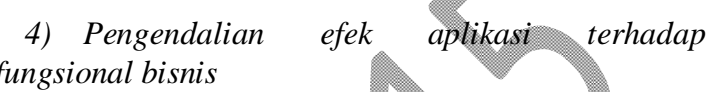

Pengendalian efek aplikasi terhadap fungsional bisnis menjadi satu-satunya pengendalian utama yang tidak merujuk pada pedoman yang disusun oleh Bellino dan Hun. Pengendalian ini ditambahkan untuk mengetahui besarnya efek yang dapat ditimbulkan aplikasi. Efek yang ditimbulkan dapat positif dan negatif?

Munculnya efek positif menunjukkan bahwa aplikasi telah berjalan sebagaimana mestinya sebagai backbone dalam operasional kerja suatu perusahaan. Berbeda ketika memberi efek negatif, hal tersebut akan membuat perusahaan untuk mengecek apa yang salah pada aplikasi. Karena ketika aplikasi menjadi backbone dan ada yang salah dengan fungsi aplikasi, makan operasional perusahaan akan ikut kacau. Untuk kontrol dan possible test yang menyertai pengendalian ini, mengacu pada best practices yang dikemukakan Davis, Schiller dan Wheeler. Hasil Audit Program yang disusun dapat dilihat pada tabel 2 . 
TABEL 1. HASIL PENILAIAN RESIKO FITUR-FITUR PADA PORTAL INTERNAL TELKOM

\begin{tabular}{|c|c|c|c|c|c|c|c|c|c|}
\hline \multirow[b]{2}{*}{ Nama Fitur } & \multicolumn{8}{|c|}{ Faktor Resiko } & \multirow[b]{2}{*}{$\begin{array}{l}\text { Nilai } \\
\text { Total }\end{array}$} \\
\hline & 竞 & 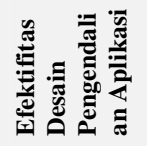 & 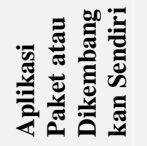 & 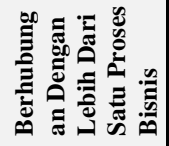 & 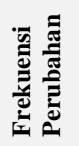 & 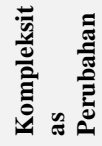 & 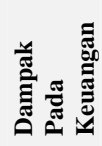 & 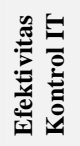 & \\
\hline Pensiun Dini (PenDi) & 4.375 & 4.25 & 4.25 & 4 & 3.625 & 3.75 & 4.625 & 4.25 & 419.375 \\
\hline e-Recruitment & 4.125 & 4.25 & 4 & 4.625 & 4.25 & 4.25 & $3.875 \pi$ & 4.25 & 418.125 \\
\hline Fast Track & 4.25 & 3.875 & 4.125 & 4.375 & 3.875 & 4 & 3.625 & 4.12 & 403.75 \\
\hline $\begin{array}{l}\text { Masa Persiapan } \\
\text { Pensiun (MPP) }\end{array}$ & 4.125 & 4.125 & 4.25 & 3.625 & 3.625 & 3.75 & 4.25 & $\begin{array}{l}4.12 \\
5\end{array}$ & 401.875 \\
\hline Retirement & 3.875 & 3.875 & 4 & 3.625 & 3.625 & & 3.75 & 4 & 382.5 \\
\hline SPPD Training & 4.625 & 4.5 & 4.5 & 4.5 & 4.625 & & 4.75 & $\begin{array}{l}4.37 \\
5\end{array}$ & 455.625 \\
\hline e-Learning & 4.375 & 4.375 & 4.25 & 4.25 & 4.25 & 4.375 & 4. & 4.5 & 430 \\
\hline $\begin{array}{l}\text { Distinct Job Manual } \\
\text { (DJM) }\end{array}$ & 4.375 & 4.125 & 4 & 4.25 & 4 & 3.75 & 3.875 & $\begin{array}{l}4.37 \\
5\end{array}$ & 412.5 \\
\hline Telkom Learning Card & 4 & 4.125 & 4 & 48 & 4.125 & 4.125 & 3.625 & $\begin{array}{l}4.37 \\
5\end{array}$ & 403.75 \\
\hline Collaboration Center & 3.75 & 4.125 & 3.75 & & 4.5 & 3.75 & 3.75 & $\begin{array}{l}4.12 \\
5\end{array}$ & 396.875 \\
\hline Portal Berita & 3.875 & 4 & 3.5 & 3.75 & 4 & 3.875 & 3.75 & 4 & 385 \\
\hline Slip Gaji & 4.5 & 4.5 & 4.375 & 4.625 & 4.25 & 4.25 & 4.875 & $\begin{array}{l}4.12 \\
5\end{array}$ & 445 \\
\hline $\begin{array}{l}\text { Surat Pajak Tahunan } \\
\text { (SPT) }\end{array}$ & 4.25 & 4.125 & $\overline{4.2}$ & 4.125 & 4.25 & 4.25 & 4.375 & 4.25 & 424.375 \\
\hline Cuti & 4 & 4.25 & 4.125 & 4.25 & 4.125 & 4.125 & 4.625 & 4.25 & 421.875 \\
\hline Presensi & 4.375 & 4.25 & 4.125 & 4.5 & 4.125 & 4 & 4.125 & $\begin{array}{l}4.12 \\
5\end{array}$ & 421.25 \\
\hline $\begin{array}{l}\text { Info Kesehatan } \\
\text { (YaKes) }\end{array}$ & 4.25 & 4 & 4 & 4.125 & 4 & 4 & 3.875 & $\begin{array}{l}4.12 \\
5\end{array}$ & 406.25 \\
\hline $\begin{array}{l}\text { HR Tools (Facility } \\
\text { Management) }\end{array}$ & 3.875 & 4.125 & 4 & 3.875 & 4 & 4.25 & 3.5 & 4 & 392.5 \\
\hline SKI/NKI & 4.625 & 425 & 4.25 & 4.5 & 4.125 & 4.125 & 4.75 & 4.25 & 440 \\
\hline Kampiun & $4.25^{\circ}$ & 4.375 & 4 & 4.25 & 4 & 4.375 & 3.75 & $\begin{array}{l}4.37 \\
5\end{array}$ & 416.875 \\
\hline Competency Asessment & 4.125 & 4.25 & 4.25 & 4.375 & 3.75 & 3.625 & 4.125 & $\begin{array}{l}4.37 \\
5\end{array}$ & 412.5 \\
\hline$\overline{C E O}$ Message & 4.125 & 4.25 & 4.125 & 4.125 & 4 & 4 & 3.5 & $\begin{array}{l}3.87 \\
5\end{array}$ & 398.125 \\
\hline
\end{tabular}

TABEL 2. Hasil Audit PRogram Untuk Pengendalian APLiKasi

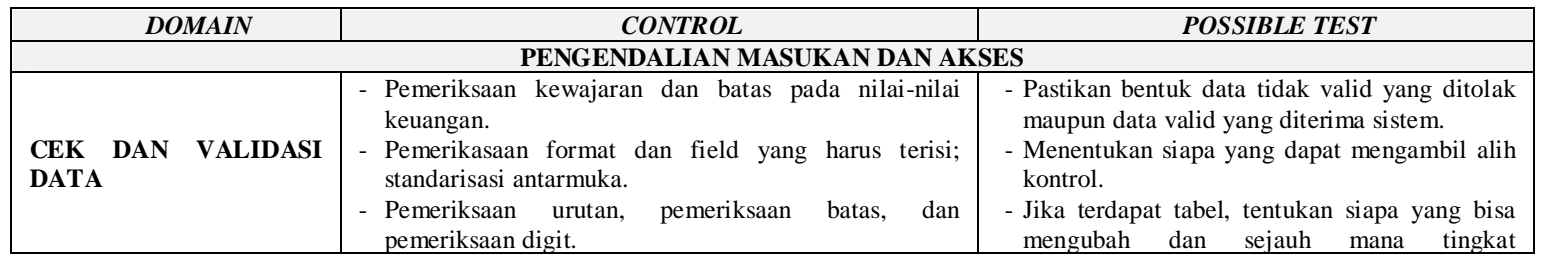




\begin{tabular}{|c|c|c|}
\hline DOMAIN & CONTROL & POSSIBLE TEST \\
\hline & $\begin{array}{l}\text { - Pemeriksaan silang } \\
\text { - Validasi (misalnya, hubungan table data dan drop- } \\
\text { down menu berisi item yang valid) }\end{array}$ & toleransinya. \\
\hline $\begin{array}{l}\text { OTORISASI, } \\
\text { PERSETUJUAN DAN } \\
\text { OVERRIDE OTOMATIS }\end{array}$ & $\begin{array}{l}\text { - Otorisasi dan persetujuan hak. Pengalokasian kepada } \\
\text { pengguna berdasarkan peran mereka dan kebutuhan } \\
\text { mereka dalam menggunakan aplikasi ini. } \\
\text { - Kemampuan Override, dibatasi oleh peran pengguna } \\
\text { dan perlu menggunakan aplikasi yang langsung } \\
\text { berhubungan dengan manajemen. }\end{array}$ & $\begin{array}{l}\text { - Lakukan tes berdasarkan pengaturan hak } \\
\text { akses user. } \\
\text { - Cek adanya fungsi administrator. }\end{array}$ \\
\hline $\begin{array}{ll}\text { PEMISAHAN } & \text { TUGAS } \\
\text { DAN HAK } & \text { AKSES } \\
\text { OTOMATIS } & \end{array}$ & $\begin{array}{l}\text { Mengkaji dan mengevaluasi mekanisme otorisasi } \\
\text { aplikasi untuk memastikan bahwa pengguna tidak } \\
\text { diperbolehkan untuk mengakses transaksi sensitif atau } \\
\text { data tanpa terlebih dahulu disahkan oleh mekanisme } \\
\text { keamanan sistem. }\end{array}$ & $\begin{array}{l}\text { - Cek hak-hak yang didapat tiap user untuk } \\
\text { menggunakan aplikasi sesuai dengan lingkup } \\
\text { kerjanya. }\end{array}$ \\
\hline PENUNDAAN ITEM & $\begin{array}{l}\text { - Laporan lama tapi menggunakan kebijakan baru } \\
\text { dengan proses yang tidak lengkap perlu adanya } \\
\text { peninjauan ulang baik harian maupun mingguan oleh } \\
\text { supervisor } \\
\text { - Adanya file yang tertunda dikarenakan informasi yang } \\
\text { diperlukan tidak cukup untuk diproses. }\end{array}$ & $\begin{array}{l}\text { - Meninjau hasil yang lama dar bukti tinjauan } \\
\text { supervisor. } \\
\text { - Menelusur melalui sampel item dini dan ke } \\
\text { laporantama atau berkas yang terinda. }\end{array}$ \\
\hline \multicolumn{3}{|c|}{ PENGENDALIAN FILE DAN TRANSMISI DATA } \\
\hline $\begin{array}{l}\text { PENGENDALIAN } \\
\text { TRANSMISI FILE }\end{array}$ & $\begin{array}{l}\text { Memeriksa kelengkapan dan keabsahan konten, termasuk } \\
\text { tanggal dan waktu, ukuran data, jumlah data, dan } \\
\text { otentikasi sumber. }\end{array}$ & $\begin{array}{l}\text { Meninjau aktifitas aplikasi melalui log } \\
\text { aplikasi. } \\
\text { - Amati validitas dan kelengkapan parameter } \\
\text { dan pengaturan. } \\
\text { - Tinjau akses. untuk mengatur dan mengubah } \\
\text { konfigurasis parameter pada transfer file. }\end{array}$ \\
\hline $\begin{array}{l}\text { PENGENDALIAN } \\
\text { TRANSMISI DATA }\end{array}$ & $\begin{array}{l}\text { Mengontrol pemilihan masukan uâtuk memvalidasi } \\
\text { peneriman data. (misalnya, field knnci, kewajaran, dan } \\
\text { lain-lain). }\end{array}$ & $\begin{array}{l}\text { - Sampel uji masing-masing skenario. } \\
\text { - Amati upaya untuk memasukkan data yang } \\
\text { tidak benar. } \\
\text { - Menentukan siapa yang dapat melakukan } \\
\text { override. } \\
\text { - Jika terdapat tabel, menentukan siapa yang } \\
\text { bisa mengubah dan sejauh mana tingkat } \\
\text { toleransinya. }\end{array}$ \\
\hline \multicolumn{3}{|c|}{ PENGENDALIAN PROSES } \\
\hline $\begin{array}{lr}\text { IDENTIFIKASI } & \text { DAN } \\
\text { VALIDASI } & \text { FILE } \\
\text { OTOMATIS } & \\
\end{array}$ & File untuk pengol & Tinjau proses untuk validasi dan uji operasi. \\
\hline $\begin{array}{l}\text { FUNGSI OTOMATIS } \\
\text { DAN PERHITUNGAN }\end{array}$ & $\begin{array}{l}\text { - Perhitungan tertentu yane dilakukan pada satu atau } \\
\text { lebin masukan dan elenten data yang tersimpan } \\
\text { nenghasilkan elemen data lebih lanjut. } \\
\text { Penggunaan tabel data yang ada (misalnya, file induk } \\
\text { atau data urutan seperti tabel rating). }\end{array}$ & $\begin{array}{l}\text { - Bandingkan nilai input dan nilai output untuk } \\
\text { semua skenario dengan langkah sistematis dan } \\
\text { pengulangan proses. } \\
\text { - Tinjau tabel kontrol pemeliharaan dan } \\
\text { tentukan siapa yang dapat mengubah serta } \\
\text { sejauh mana tingkat toleransinya. }\end{array}$ \\
\hline $\begin{array}{l}\text { AUDIT TF } \\
\text { OVERRIDE }\end{array}$ & $\begin{array}{l}\text { - Pelacakan otomatis terhadap perubahan yang dibuat } \\
\text { untuk data, hubungkan perubahan dengan pengguna } \\
\text { tertentu. } \\
\text { Pelacakan otomatis dan soroti mekanisme override } \\
\text { untuk proses normal. }\end{array}$ & $\begin{array}{l}\text { Meninjau keberadaan } \log \text { aplikasi. Cek } \\
\text { dengan melihat aktivitas terakhir yang dilakukan } \\
\text { pada aplikasi. }\end{array}$ \\
\hline $\begin{array}{l}\text { EKSTRAKRI } \\
\text { PENYARINGA } \\
\text { PELAPORAN }\end{array}$ & $\begin{array}{l}\text { Ekstrak output rutin dievaluasi terkait dengan } \\
\text { kewajaran dan kelengkapan. } \\
\text { - Alokasi transaksi otomatis } \\
\text { - Evaluasi data yang digunakan dalam melakukan } \\
\text { estimasi untuk tujuan laporan keuangan. }\end{array}$ & $\begin{array}{l}\text { - Meninjau desain ekstrak rutin terhadap file } \\
\text { data yang digunakan. } \\
\text { - Meninjau penilaian pengawas terhadap output } \\
\text { dari ekstraksi rutin pada data sebagai bukti } \\
\text { peninjauan dan tantangan. } \\
\text { - Sampel ulasan alokasi untuk kesesuaian. } \\
\text { - Meninjau proses penilaian ekstraksi data untuk } \\
\text { kelengkapan dan validitas. }\end{array}$ \\
\hline $\begin{array}{l}\text { PENYEIMBANGAN } \\
\text { ANTARMUKA }\end{array}$ & $\begin{array}{l}\text { - Pemeriksaan otomatis data yang diterima dari sistem } \\
\text { lainnya (misalnya, gaji, klaim data, dll) ke dalam } \\
\text { datawarehouse atau sistem buku besar. } \\
\text { - Pemeriksaan otomatis bahwa saldo pada kedua sistem } \\
\text { sesuai, atau jika tidak, laporan pengecualian dihasilkan } \\
\text { dan digunakan. }\end{array}$ & $\begin{array}{l}\text { - Periksa laporan kesalahan yang ada pada } \\
\text { antarmuka. } \\
\text { - Periksa keabsahan dan kelengkapan parameter } \\
\text { dan pengaturan. } \\
\text { - Tinjau akses untuk mengatur dan } \\
\text { pengkonfigurasian ulang parameter pada } \\
\text { antarmuka. } \\
\text { - Periksa bukti laporan kesesuaian, cek, dan } \\
\text { pengolahan file error. }\end{array}$ \\
\hline CEK DUPLIKASI DATA & $\begin{array}{l}\text { - Perbandingan transaksi individu dengan catatan } \\
\text { transaksi sebelumnya untuk pencocokan. } \\
\text { - Perbandingan file individu untuk tanggal yang }\end{array}$ & $\begin{array}{lllr}\text { - Tinjau akses untuk } & \text { mengatur } & \text { dan } \\
\text { pengkonfigurasian } & \text { ulang } & \text { parameter } & \text { pada } \\
\text { duplikasi transaksi atau file. } & & \\
\end{array}$ \\
\hline
\end{tabular}




\begin{tabular}{|c|c|c|}
\hline DOMAIN & CONTROL & POSSIBLE TEST \\
\hline & diharapkan, waktu, ukuran, dll. & $\begin{array}{l}\text { - Tinjau kembali proses penanganan untuk } \\
\text { penolakan file atau transaksi. } \\
\text { - Cek adanya pemisahan data sebagai master } \\
\text { data dan backup data. }\end{array}$ \\
\hline \multicolumn{3}{|c|}{ PENGENDALIAN KELUARAN } \\
\hline $\begin{array}{l}\text { PENGENDALIAN } \\
\text { DISTRIBUSI } \\
\text { LAPORAN }\end{array}$ & $\begin{array}{l}\text { - Memastikan laporan valid sesuai kondisi yang ada } \\
\text { - Memastikan laporan tidak hilang } \\
\text { - Laporan tidak dapat diakses oleh pihak yang tidak } \\
\text { berwenang }\end{array}$ & $\begin{array}{l}\text { - Lakukan wawancara terkait terhadap } \\
\text { perlakuan laporan yang tercetak } \\
\text { - Memastikan keamanan akses laporan baik } \\
\text { cetak maupun digital }\end{array}$ \\
\hline \multicolumn{3}{|c|}{ PENGENDALIAN FILE MASTER DAN STANDING DATA } \\
\hline $\begin{array}{l}\text { PEMBAHARUAN } \\
\text { OTORISASI }\end{array}$ & $\begin{array}{l}\text { Akses untuk memperbarui pengalokasian hak untuk } \\
\text { pengguna berdasarkan peran dan kebutuhan dalam } \\
\text { menggunakan aplikasi. }\end{array}$ & $\begin{array}{l}\text { - Tinjau akses untuk mengatur dan mengubah } \\
\text { file induk dan data lainnya. } \\
\text { - Memastikan proses deprovisioning telah } \\
\text { dilakukan sebagaimana mestinya. }\end{array}$ \\
\hline \multicolumn{3}{|c|}{ PENGENDALIAN EFEK APLIKASI TERHADAP FUNGSIONAL BISNIS } \\
\hline $\begin{array}{lr}\text { MENINJAU DAMPAK } \\
\text { APLIKASI } \\
\text { PROSES BISNIS }\end{array}$ & $\begin{array}{l}\text { Menentukan apakah Business Impact Analysis (BIA) telah } \\
\text { dilakukan pada aplikasi untuk membangun cadangan dan } \\
\text { pemulihan kebutuhan. }\end{array}$ & $\begin{array}{l}\text { Wawancara dengan tim application support dan } \\
\text { end-user, memasilan eksistensi BIA, jika ada } \\
\text { lakukan review. }\end{array}$ \\
\hline
\end{tabular}

\section{Uji Coba Audit Program}

Uji coba audit program dilakukan dengan kembali menyusun skenario baru untuk melakukan pengujian. Hal ini dilakukan karena audit program yang disusun bertujuan agar bisa digunakan secara umum dalam hal ini digunakan untuk melakukan pengendalian aplikasi pada perusahaan-perusahaan yang membutuhkan kegiatan pengendalian aplikasi untuk memastikan aplikasinya berjalan sesuai dengan keinginan. Sedangkan ketika menguji coba, dalam hal ini studi kasus pada Telkom, audit program perlu adanya penyesuaian dengan menampilkan actual test. Actual test disusun berdasarkan kondisi aplikasi secara real. Tiap aplikasi pada tiap perusahaan, memiliki latar belakang proses yang berbeda-beda, hal ini yang menyebabkan perlu adanya actual test disamping possible test yang telah disusun pada audit program. Actual test disusun tetap dalam kaidah possible test yang telah ada.

Dalam melakukan uji coba pada studi kasus, tahap awal telah dilakukan dengan melakukan pemilahan aplikasi melalui penilaian resiko. Penilaian resiko menghasilkan daftar fitur dengan tingkat resiko terbesar. Fitur yang memiliki nilai resiko tinggi adalah SPPD Training. Dari beberapa fitur yang ada pada portal internal Telkom, uji coba hanya dapat dilakukan pada satu fitur. Hal ini dikarenakan penulis hanya mendapatkan akses untuk menggunakan satu fitur saja sebagai studi kasus untuk melakukan pengendalian aplikasi.

Berikutnya dalam menguji coba audit program, Telkom hanya memberikan ijin untuk menilai efektifitas aplikasi melalui program simulasi. Pihak eksternal yang tidak berkepentingan langsung dengan aplikasi tidak diberi ijin untuk melihat atau mencoba aplikasi dengan lebih rinci. Hal tersebut dikarenakan aplikasi sedang dalam penggunaan. Dikhawatirkan ketika ada pihak eksternal yang terlibat akses aplikasi, akan mengganggu kinerja dari aplikasi itu sendiri.
Hasil review dari simulasi SPPD Training yang sudah berjalan menjadi tulang pungsung Telkom pada fungsional pelathan dan pengembangan sudah cukup efekif. Pada pengendalian akses dan masukan hak akses user bergantung dari keperluan user menggunakan fitur SPPD Training. Ketika user perlu melakukan approve untuk memposting dokumen SPPD, maka sistem hanya dapat melakukan proses posting begitu juga untuk atasan yang membutahkan akses untuk menyetujui kegiatan. Fuñgsi administrator juga telah ada, hanya pada fitur SPPD Training, fungsi administrator hanya membantu user dalam memproses perubahanperubahan yang terjadi ketika kegiatan sudah disetujui, semisal ada pergantian tempat, ataupun yang lainnya. Meskipun terdapat admin yang membantu memperbaiki data, namun ketika awal pengajuan kegiatan terdapat hal yang tidak valid, akan mengakibatkan adanya penolakan ketika akan masuk tahap posting dan pembuat dokumen diharapkan melakukan re-evaluate dokumen. Pemrosesan kegiatan pun melalui SPPD Training dapat cepat dilakukan, sehingga tidak memunculkan data-data yang lama tertunda. Hal tersebut dikarenakan adanya fitur notifikasi yang memberitahukan bahwa ada data yang perlu diproses.

Pada pemrosesan data, validasi dilakukan secara manual, namun tetap dalam sistem. Proses manual yang dimaksud adalah peninjauan yang dilakukan terkait kelengkapan data pengajuan seperti nama penanggung jawab, jenis training, peserta training, tempat training dan pengajuan nominal anggaran. Hal tersebut dilakukan ketika data akan diposting ke dalam SPPD Training untuk selanjutnya masuk pada proses persetujuan. Semua proses yang ada akan selalu tercatat pada log aplikasi. Sehingga ketika nantinya data training diproses dan mengalami perbaikan yang tentunya melalui admin, akan dapat dilacak kebenarannya melalui log aplikasi.

Pengendalian keluaran pada SPPD Training terdapat 2 jenis keluaran, yakni cetak dan digital. Untuk laporan tercetak, hanya berlaku tiga tahun 
sejak laporan tercetak sebagai arsip. Untuk selanjutnya akan dimusnahkan. Hak akses laporan tersebut hanya dapat dilihat pihak-pihak yang memang mempunyai wewenang/urusan untuk melihatnya. Arsip untuk masing-masing file telah dipilah berdasakan lingkup berlakunya laporan. Untuk laporan digital, hak akses melalui sistem telah dipilah sesuai dengan hak akses user. Hal ini lebih aman karena hak akses user telah ditentukan di awal. Untuk masa berlaku sama dengan laporan cetak, yakni tiga tahun.

Untuk pengendalian file master dan standing data, file induk pada fitur SPPD Training hanya bisa diubah oleh admin SAP. Dalam hal ini berbeda dengan perubahan data training yang diinput, karena hal teresbut bisa dilakukan oleh admin SPPD melalui permintaan user. Dan perubahan tersebut hanya dikarenakan adanya perubahan data training. Begitu juga dengan data user, yang dapat mengubah hanya admin SAP. Ada perbedaan jenis data pada sistem Telkom secara keseluruhan. Hal ini dikarenakan SPPD Training hanya salah satu fitur dari portal internal Telkom yang merupakan aplikasi yang menjembatani antara user dengan SAP. Tujuan dilakukannya perbedaan dikarenakan SAP memilik data yang saling terkait antara satu fungsional dengan fungsional lainnya sehingga akan sangat rawan bila banyak akses masuk ke sistem SAP.

\section{KESIMPULAN DAN SARAN}

Dalam menyusun audit program antuk pengendalian aplikasi pada sistem terintegrasi dapat disimpulkan bahwa :

1. Audit program untuk pengendalian aphkasi disesuaikan dengan memodifikasi beberapa hal yang ada pada kerangka utama. Penyesuaian dilakukan dengan membandingkan kerangka utama dengan literatur lain yang berhubungan. Penyesuaian yang dilakukan antara lain menambah 1 poin pengendalian utama, yakni pengendalian terhadap efek aplikasi terhadap fungsional bisnis. Selain itu, penyesuaian juga dilakukan pada beberapa jenis control untuk beberapa domain yang ada di kerangka utama.

2. Audit program yang disusun dapat digunakan pada salah satu fitur pada portal internal
Telkom, yakni SPPD Training. Berdasarkan hasil ujicoba, dapat dilihat bahwa fitur SPPD Training telah berjalan efektif dan efisien. Mulai penetapan peserta training hingga alokasi budget untuk melakukan training tersebut. Demikian juga perihal mekanisme sistem yang dapat ditelusuri ketika ada kesalahan atau penyesuaian data. Hal tersebut membuktikan bahwa audit program dapat digunakan untuk melakukan pengendalian aplikasi.

Penelitian yang sudah dilakukan memiliki ruang lingkup sistem terintegrasi. Namun uji coba yang dilakukan hanya sebatas salah salu fitur atau aplikasi. Dalam penelitian selanjutnya, disarankan untuk menggunakan aplikasi atau fitur yang lebih dari satu pada sistem terintegrasi. Sehingga pengendalian aplikasi yang dilakukan dapat mengetahui secara lebih rinci baik keunggulan maupun kelemahan sistem yang dilakukan pengendalian aplikasi agar dapat segera diperbaiki.

\section{DAFT AR PUSTAKA}

[1] Bellino, C. \& Hunt, S. (2007). Auditing Application Controls. Flonda: The Institute Internal Auditors.

[2] Davis, C. Schiller, M., \& Wheeler, K. (2011). IT Auditing: Using Controls to Protect Information Assets. McGraw Hill.

[3]. Isa, I. (2012). Evaluasi Pengontrolan Sistem Informasi. Yogyakarta: Graha Ilmu.

[4] Setyawan, C. A. (2009). Audit SIstem Informasi Terkomputerisasi Atas Pengendalian Aplikasi Sistem Pembelian Indra Optik . Skripsi, Petra Christian University.

[5] van Dijk, N. (2009). Provisioning and Deprovisioning Services in Identity Federations.

[6] Weber, R. (1999). Information Systems Control and Audit. New Jersey: Prentice-Hall. 